\title{
Selective sulfonylation and isonitrilation of para-quinone methides employing TosMIC as a source of sulfonyl group or isonitrile group
}

\author{
Chuanhua Qu, Run Huang, Yong Li, Tong Liu, Yuan Chen and Guiting Song*
}

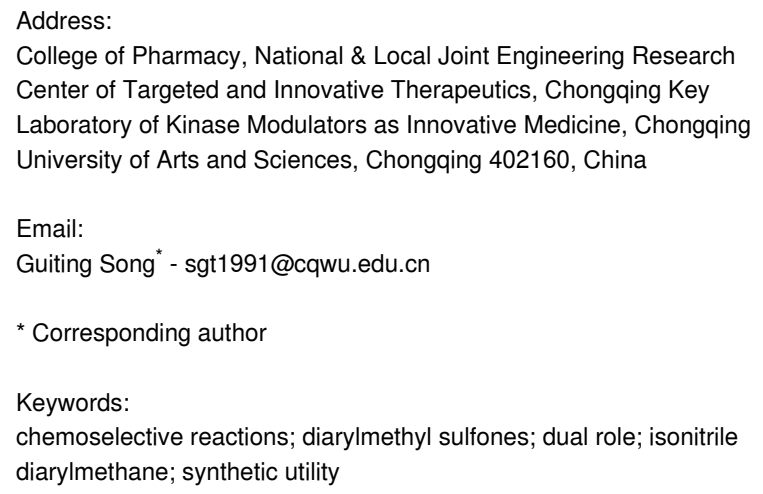

\author{
Beilstein J. Org. Chem. 2021, 17, 2822-2831. \\ https://doi.org/10.3762/bjoc.17.193 \\ Received: 21 August 2021 \\ Accepted: 21 November 2021 \\ Published: 02 December 2021 \\ Associate Editor: M. Rueping \\ (C) 2021 Qu et al.; licensee Beilstein-Institut. \\ License and terms: see end of document.
}

\begin{abstract}
Chemoselective sulfonylation and isonitrilation reactions for the divergent synthesis of valuable diarylmethyl sulfones and isonitrile diarylmethanes starting from easy-to-synthesize para-quinone methides ( $p$-QMs) and commercially abundant $p$-toluenesulfonylmethyl isocyanide (TosMIC) by using respectively zinc iodide and 1,8-diazabicyclo[5.4.0]undec-7-ene (DBU) as catalysts were developed. The distinguishing feature of this method is that TosMIC plays a dual role from the same substrates in the reaction: as a sulfonyl source or as an isonitrile source. The synthetic utility of this protocol was also demonstrated in the synthesis of difluoroalkylated diarylmethane 5 and diarylmethane ketone derivatives $\mathbf{6}$ and 7, which are important core structures in natural products and medicines.
\end{abstract}

\section{Introduction}

Sulfones are ubiquitous units commonly found in marketed drugs and natural products. Because of their unique electronic and structural properties, they are often used in medicinal chemistry programs to search for anti-inflammatory, anti-HIV, antimicrobial, antimalarial, and anticancer activities [1,2]. Diarylmethane motifs are widely present in natural products and pharmaceuticals that exhibit extraordinary biological activity $[3,4]$ (Figure 1). Among them, their anticancer activity is particularly attractive, demonstrated by drugs such as letrozole [5] and entrectinib [6], with especially entrectinib showing a potent anticancer activity against a broad spectrum of human cancer cell lines. In recent decades, the construction of a hybrid system with varied biological and pharmaceutical activities has received extensive attention from medicinal chemists [7]. Therefore, merging the diarylmethane unit with the sulfonyl motif to assemble the sulfonyl diarylmethane skeleton has 
attractive potential application value and provides the possibility for drug discovery [8-10] (Figure 1). Consequently, the development of a rapid access to diarylmethyl sulfones is a valuable and appealing task in synthetic chemistry.

Traditionally, diarylmethyl sulfones are synthesized by transition-metal-catalyzed deoxy $\mathrm{C}-\mathrm{S}$ bond-coupling reaction of sodium arylsulfinates with diarylmethanols [11], $\mathrm{C}-\mathrm{H}$ functionalization of alkyl sulfones with aryl halides [12], and via a reductive strategy through nitrogen loss of sulfonyl hydrazones [13,14] In addition, a sulfa-1,6-conjugated addition reaction [15-17] has also been developed for this purpose. Most of the reported methods are affected by long reaction times and the need for expensive metal catalysts or reagents. Therefore, there is great need to develop a more effective and rapid method for preparing diaryl methyl sulfones.

$p$-Toluenesulfonylmethyl isocyanide (TosMIC), a versatile synthon in organic chemistry, has been widely used to synthesize a myriad of valuable chemicals due to its high reactivity shown by the combination of acidic $\alpha$-carbon atoms, isocyano groups, and sulfonyl moieties [18]. In general, TosMIC undergoes base-mediated 1,3-dipolar cycloadditions with activated alkenes to provide pyrroles as products [18] (Scheme 1A). Recently, alternative functionalizations using TosMIC as a tosyl source of arylalkenes or alkynes provided an attractive option for the synthesis of vinyl sulfones [19-23] (Scheme 1B). However, in contrast to the reaction of TosMIC as tosyl source with various aryl olefins, reports relating to reactions of TosMIC with electron-deficient olefins such as $p$-QMs for the preparation of highly valuable diarylmethyl sulfones are relatively scarce [24]. In addition, the important link between structural diversity and complexity with bioactivity represented by sulfones has led to the goal of developing strategies to as many these pivotal scaffolds as possible.

Isocyanide is an important $\mathrm{C} 1$ synthon. Its special reactivity, such as the ability to react with electrophilic, nucleophilic, and radical reagents [25-28], determines that it can participate in many types of reactions such as multicomponent reactions [2932], tandem reactions [33,34], and insertion reactions [35-39], etc. In this context, the electron-rich aryl(phenol)methane isonitrile may be a new active unit, which can be seen from the previous case of $p$-QMs type reaction [40-51] and the abovementioned properties of isocyanide.

Herein, we report the chemoselective sulfonylation and isonitrilation of $p-\mathrm{QMs}$ by changing the reaction conditions. This new general protocol allows, from the same substrates $p$-QMs 1 and $p$-tosylmethyl isocyanide (TosMIC, 2a), the formation of<smiles>COc1cc([C@H]2c3cc4c(cc3[C@@H](O)C3COC(=O)[C@H]32)OCO4)cc(OC)c1OC</smiles>

podophyllotoxin antitumor natural product<smiles>Cc1ccc(O)c(C(CCN(C(C)C)C(C)C)c2ccccc2)c1</smiles>

tolterodine drug for urinary incontinence<smiles>N#Cc1ccc(C(c2ccc(C#N)cc2)n2cncn2)cc1</smiles>

letrozole anti-breast cancer drug<smiles>CN1CCN(c2ccc(C(=O)Nc3n[nH]c4ccc(Cc5cc(F)cc(F)c5)cc34)c(NC3CCOCC3)c2)CC1</smiles>

entrectinib drug for non-small cell carcinoma solid tumor drugs<smiles>COc1ccc(S(=O)(=O)C2c3ccccc3-c3ccccc32)cc1</smiles>
anticancer agent

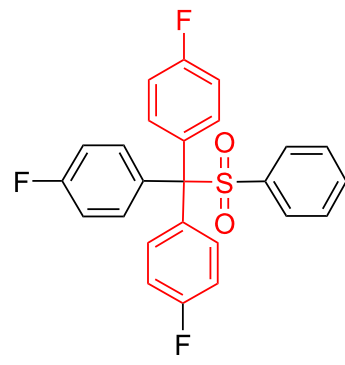

II

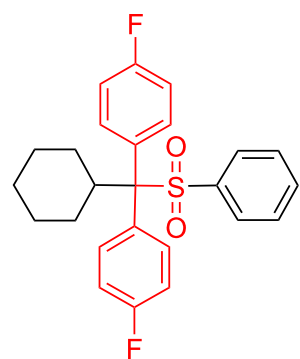

III

potassium channel inhibitors<smiles>CN1CCN(c2ccc3ccccc3c2)c2cc(S(=O)(=O)C(c3ccc4ccccc4c3)c3ccc4ccccc4c3)ccc2C1</smiles>

IV 
A. general approach to pyrrole synthesis using TosMIC with electron-deficient olefins

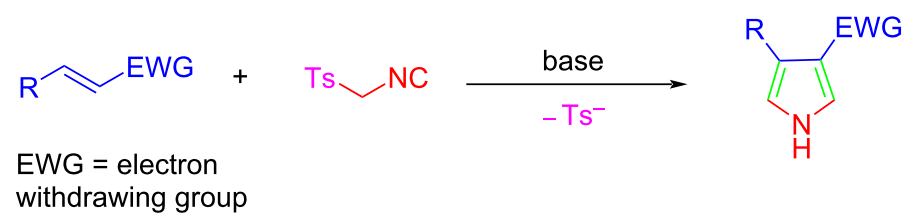

B. TosMIC as a tosyl source in the reactions with electron-rich aromatic olefins<smiles>[R]C=C[Bi]</smiles>

C. TosMIC as a tosyl or isonitrile source in the reaction with $p$-QMs (this work)

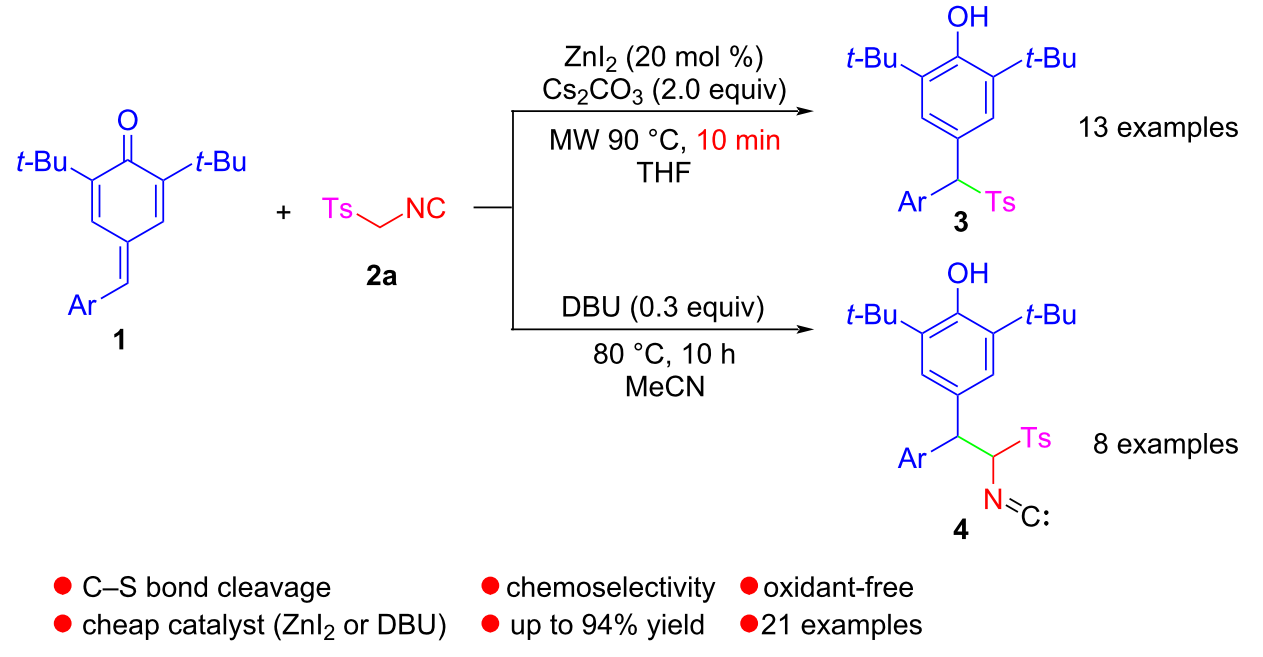

Scheme 1: The chemistry of TosMIC in the reactions with olefins.

quite different products $\mathbf{3}$ or $\mathbf{4}$ in a simple and mild manner, which provides an efficient entry into the rapid assembly of various diarylmethyl sulfones and isonitrile diarylmethanes (Scheme 1C).

\section{Results and Discussion}

We commenced the study by using $p$-QMs 1a and TosMIC (2a) as model substrates to optimize the reaction conditions. As shown in Table 1, when 1a and 2a were treated with $20 \mathrm{~mol} \%$ $\mathrm{Ag}_{2} \mathrm{CO}_{3}$ in THF in the presence of $\mathrm{Cs}_{2} \mathrm{CO}_{3}$ at $90{ }^{\circ} \mathrm{C}$ under microwave irradiation for $10 \mathrm{~min}$, fortunately, the sulfonylated diarylmethane product 3a was isolated in 36\% yield (Table 1, entry 2). When $\mathrm{ZnI}_{2}$ or $\mathrm{Cu}(\mathrm{OAc})_{2}$ was used instead of $\mathrm{Ag}_{2} \mathrm{CO}_{3}$, we found that the yield of 3 a catalyzed by $\mathrm{ZnI}_{2}$ reached $94 \%$ (Table 1, entry 3 ), and the reaction with $\mathrm{Cu}_{2}(\mathrm{OAc})_{2}$ as a catalyst did not proceed smoothly (Table 1 , entry 1 ). Other bases such as $\mathrm{CH}_{3} \mathrm{ONa}$ or $t$ - $\mathrm{BuONa}$ (Table 1, entries 4 and 5) were then investigated and no better result was found. In the follow- up control experiments, we studied the reaction without adding bases, and unexpectedly found Ag salts could catalyze the 1,6conjugate addition of TosMIC (2a) and $p$-QM 1a to provide aryl(phenol)methane isonitrile $4 \mathbf{a}$ under base-free conditions (Table 1, entries 6-8). When the silver salt was removed from the reaction conditions, the reaction did not proceed (Table 1, entry 9). Then, we investigated the effect of a catalytic amount of DBU on the reaction and found that reaction efficiency did not decrease, indicating that the reaction could also be catalyzed by DBU (Table 1, entry 10). When DABCO (triethylene diamine) was used instead of DBU, the reaction also proceeded, however, the reaction efficiency was lower compared to DBU (Table 1, entry 11).

After identifying the optimal conditions, we first evaluated the substrate scope of the sulfonylation reaction. As shown in Scheme 2, various substituted $p$-QMs were readily transformed in this sulfonylation reaction, providing the corresponding 
Table 1: Optimization of the reaction conditions for the sulfonylation and isonitrilation of $p$-quinone methides with TosMIC. ${ }^{a}$<smiles>CC(C)(C)C1=CC(=Cc2ccccc2)C=C(C(C)(C)C)C1=O</smiles>

1a

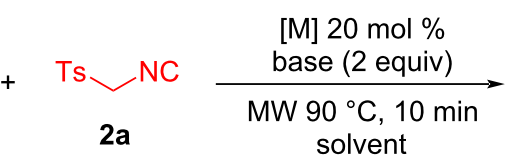<smiles>CC(C)(C)c1cc(C(F)(F)c2ccccc2)cc(C(C)(C)C)c1O</smiles>

$3 a-\mathrm{CH}_{2} \mathrm{NC}$ or<smiles>CC(C)(C)c1cc(C(C(C#N)c2ccccc2)C(F)(F)F)cc(C(C)(C)C)c1O</smiles>

4a

\begin{tabular}{|c|c|c|c|c|c|}
\hline Entry & [M] $(20 \mathrm{~mol} \%)$ & Solvent & Base & Yield of $\mathbf{3 a}(\%)^{b}$ & Yield of $4 a(\%)^{b}$ \\
\hline 1 & $\mathrm{Cu}(\mathrm{OAc})_{2}$ & THF & $\mathrm{Cs}_{2} \mathrm{CO}_{3}$ & trace & - \\
\hline 2 & $\mathrm{Ag}_{2} \mathrm{CO}_{3}$ & THF & $\mathrm{Cs}_{2} \mathrm{CO}_{3}$ & 36 & - \\
\hline 3 & $\mathrm{ZnI}_{2}$ & THF & $\mathrm{Cs}_{2} \mathrm{CO}_{3}$ & 94 & - \\
\hline 4 & $\mathrm{ZnI}_{2}$ & THF & $\mathrm{CH}_{3} \mathrm{ONa}$ & 61 & - \\
\hline 5 & $\mathrm{ZnI}_{2}$ & THF & $t$-BuONa & 50 & - \\
\hline $6^{c}$ & $\mathrm{Ag}_{2} \mathrm{CO}_{3}$ & $\mathrm{MeCN}$ & - & - & $67(\mathrm{dr}=1: 1)$ \\
\hline $7^{c}$ & $\mathrm{Ag}_{2} \mathrm{O}$ & $\mathrm{MeCN}$ & - & - & $63(d r=1: 1)$ \\
\hline $8^{c}$ & AgOTs & $\mathrm{MeCN}$ & - & - & $81(d r=1: 1)$ \\
\hline $9^{c}$ & - & $\mathrm{MeCN}$ & - & - & trace \\
\hline $10^{c, d}$ & - & $\mathrm{MeCN}$ & DBU & - & $82(\mathrm{dr}=1: 1)$ \\
\hline $11^{c, d}$ & - & $\mathrm{MeCN}$ & DABCO & - & $61(d r=1: 1)$ \\
\hline
\end{tabular}

aReactions were performed on a $0.2 \mathrm{mmol}$ scale of $1 \mathrm{a}$ using 2.0 equiv of $2 \mathrm{a}, 20 \mathrm{~mol} \%$ [M], and 2.0 equiv of base, $\mathrm{MW}, 90{ }^{\circ} \mathrm{C}, 10 \mathrm{~min} ;{ }^{b}$ yields refer to the products isolated by column chromatography; ${ }^{\mathrm{c}} 80^{\circ} \mathrm{C}$ oil bath for $10 \mathrm{~h}$ was used; ${ }^{\mathrm{d}} 0.3$ equiv DBU or DABCO was used.

sulfonylated diarylmethane derivatives with good to excellent yields. Both electron-donating groups and electron-withdrawing substituents located in the para-, ortho-, or meta-position of the $p$-QMs were well tolerated and furnished the desired products $3 \mathbf{a}-\mathbf{m}$ in good yields (81-94\% yields). It was noteworthy that $p$-QMs bearing functional groups, such as methyl, methoxy, tert-butyl, fluoro, chloro, bromo, and trifluoromethyl were well compatible under the optimal reaction conditions. The efficiency of this method was not affected by the pattern of substituents on the phenyl ring. In particular, $p$-QMs with naphthyl $\mathbf{1 l}$ and thienyl moieties $\mathbf{1 m}$ provided the products $\mathbf{3 l}$ and 3m in good yields (90 and $87 \%$, respectively).

However, with other substituted $p$-QMs, such as Bpin, $\mathrm{CN}$, and COOMe at C-4 position, and $p$-QMs bearing 2,6-diethyl or 2,6diisopropyl, new main spots were detected by TLC, but they quickly decomposed during column chromatography so that the target products could not be obtained (Scheme 3), which might be due to the easy-to-cleave nature of the $p$-toluenesulfonyl group.

To further confirm the structure of the sulfonylated diarylmethanes, product $\mathbf{3 e}$ was chosen as a representative compound and its structure was clearly verified by single crystal X-ray diffraction analysis, as shown in Figure 2 (CCDC No. 2104242)
Next, the substrate scope of the 1,6-conjugate reaction of TosMIC to $p$-QMs was examined under optimized conditions (Table 1, entry 10). As depicted in Scheme 4, the substrate scope of $p$-QMs 1 was first examined. In general, the 1,6-conjugate reaction tolerated a wide range of $p$-QMs $\mathbf{1}$, furnishing a series of isonitrile diarylmethanes $\mathbf{4 a}-\mathbf{h}$ in good to high yields (60-88\%) with moderate diastereoselectivity. Substitution of the aryl ring of $p$-QMs 1 with functional groups such as alkyl, fluoro, bromo, trifluoromethyl, and thiophenyl was generally well tolerated $(\mathbf{4 a}-\mathbf{g})$. Further, it should be noted that other activated methylene isonitriles such as methyl isocyanoacetate (2b) were also compatible with the reaction conditions providing, for example, the product $\mathbf{4 h}$ with a yield of $86 \%$ and excellent diastereoselectivity (dr $>19: 1)$.

To further underline the utility of this transformation, several experiments were carried out (Scheme 5). First, the model reaction is scalable. When $\mathbf{1 b}(3 \mathrm{mmol})$ and $\mathbf{2 a}(6 \mathrm{mmol})$ were mixed under the standard conditions, the desired products $\mathbf{3 b}$ or 4b were obtained with yields of $92 \%$ and $88 \%$, respectively. Second, the sulfonylated diarylmethane $\mathbf{3 b}$ obtained through the $\mathrm{C}-\mathrm{S}$ bond-cleavage sulfonylation reaction is a versatile building block for preparing diarylmethane derivatives through a nucleophilic substitution process. For example, compound $\mathbf{3 b}$ reacted with difluoroenolate to form the difluoroalkylated diarylmethane 5 in $83 \%$ yield via a $\mathrm{Cu}(\mathrm{OAc})_{2}$-catalyzed 
<smiles>[10B]C([18F])c1cc(C(C)(C)C)c(O)c(C(C)(C)C)c1</smiles><smiles>CC(C)(C)c1cc(C([12F])c2ccccc2)cc(C(C)(C)C)c1O</smiles>

3a, $94 \%$<smiles>CC(C)(C)c1cc(C([12F])c2ccc(Cl)cc2)cc(C(C)(C)C)c1O</smiles>

3f, $83 \%$<smiles>Cc1ccc(C([18F])c2cc(C(C)(C)C)c(O)c(C(C)(C)C)c2)cc1C</smiles>

3k, $91 \%$<smiles>Cc1ccc(C([18F])c2cc(C(C)(C)C)c(O)c(C(C)(C)C)c2)cc1</smiles>

3b, $86 \%$<smiles>COc1ccc(C([18F])c2cc(C(C)(C)C)c(O)c(C(C)(C)C)c2)cc1</smiles>

3c, $88 \%$<smiles>CC(C)(C)c1ccc(C([18F])c2cc(C(C)(C)C)c(O)c(C(C)(C)C)c2)cc1</smiles>

3d, $85 \%$<smiles>COc1ccccc1C([12F])c1cc(C(C)(C)C)c(O)c(C(C)(C)C)c1</smiles>

3e, $89 \%$<smiles>CC(C)(C)c1cc(C([12F])c2ccccc2Br)cc(C(C)(C)C)c1O</smiles>

$3 g, 81 \%$<smiles>CC(C)(C)c1cc(C([12F])c2ccc3ccccc3c2)cc(C(C)(C)C)c1O</smiles>

3I, $90 \%$<smiles>CC(C)(C)c1cc(C([12F])c2ccc(Cl)c(Cl)c2)cc(C(C)(C)C)c1O</smiles>

3h, $85 \%$<smiles>CC(C)(C)c1cc(C([18F])c2ccc(C(F)(F)F)cc2)cc(C(C)(C)C)c1O</smiles>

3i, $\quad 88 \%$<smiles>COc1cc(C([AsH3])c2cc(C(C)(C)C)c(O)c(C(C)(C)C)c2)cc(OC)c1OC</smiles>

3j, $86 \%$<smiles>CC(C)(C)c1cc(C(C)(C)C)c(O)c(C(F)(F)F)c1</smiles>

$3 \mathrm{~m}, 87 \%$

Scheme 2: $\mathrm{Znl}_{2}$-catalyzed C-S-bond cleavage of TosMIC for the synthesis of diarylmethyl sulfones $3 \mathbf{a}-\mathbf{m}$. Reaction conditions unless otherwise specified: $1(0.2 \mathrm{mmol}), 2 \mathrm{a}(0.4 \mathrm{mmol}), \mathrm{Znl}_{2}(0.04 \mathrm{mmol}), \mathrm{Cs}_{2} \mathrm{CO}_{3}(0.4 \mathrm{mmol}), \mathrm{THF}(1.0 \mathrm{~mL}), \mathrm{MW} 90{ }^{\circ} \mathrm{C}$, under air atmosphere for $10 \mathrm{~min}$; yields are reported for the isolated products.<smiles>[R]c1ccc(C([18F])c2cc(C(C)(C)C)c(O)c(C(C)(C)C)c2)cc1</smiles>

$\mathrm{R}=$ Bpin, $\mathrm{CN}, \mathrm{COOMe}$ or<smiles>[R]c1cc(C([Hg])c2ccccc2)cc([R])c1O</smiles>

$\mathrm{R}^{1}=\mathrm{iPr}$ or Et

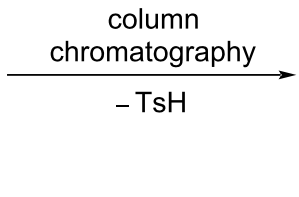<smiles>[R]C1=CC(=Cc2ccc([R])cc2)C=C([R])C1=O</smiles>

$\mathrm{R}^{1}=\mathrm{iPr}$ or Et

$\mathrm{R}=$ Bpin, $\mathrm{CN}, \mathrm{COOMe}$ 


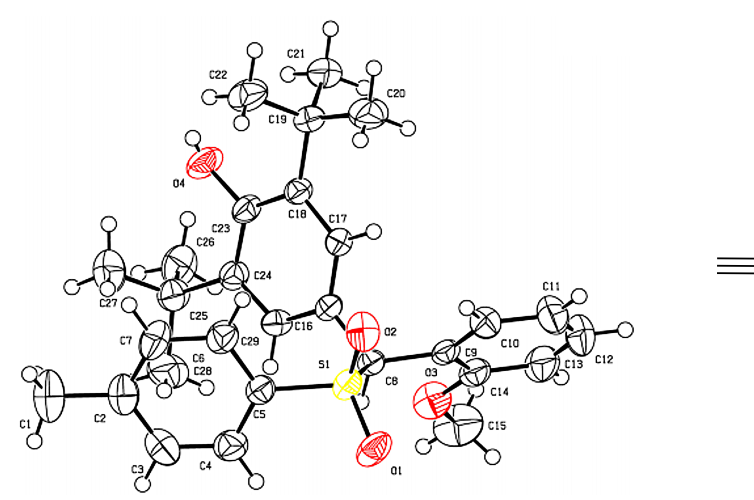<smiles>C#CC(C)(C)c1cc(C(c2ccccc2OC)S(=O)(=O)c2ccc(C)cc2)cc(C(C)(C)C)c1O</smiles>

Figure 2: Crystal structure of diarylmethyl sulfone $\mathbf{3 e .}$<smiles>CC(C)(C)C1=CC(=C[18F])C=C(C(C)(C)C)C1=O</smiles>

$$
\underset{2}{\mathrm{R}^{2} \mathrm{NC}} \stackrel{\mathrm{DBU}(0.3 \text { equiv })}{\stackrel{80{ }^{\circ} \mathrm{C}, 10 \mathrm{~h}}{\mathrm{MeCN}}}
$$<smiles>[3H]C(C(c1ccccc1)c1cc(C(C)(C)C)c(O)c(C(C)(C)C)c1)C(C)(C)C</smiles>

$( \pm)-4 a \quad 82 \%$ $\mathrm{dr}=1: 1$<smiles>[3H]C(C(c1ccc(Br)cc1)c1cc(C(C)(C)C)c(O)c(C(C)(C)C)c1)C(C)(C)C</smiles>

$( \pm)-4 e \quad 80 \%$ $\mathrm{dr}=1.1: 1$<smiles>Cc1ccc(C(c2cc(C(C)(C)C)c(O)c(C(C)(C)C)c2)C(C#N)C(F)(F)F)cc1</smiles>

$( \pm)-4 b \quad 85 \%$ $\mathrm{dr}=2: 1$<smiles>CC(C)(C)c1cc(C(c2ccc(C(F)(F)F)cc2)C([As])C#N)cc(C(C)(C)C)c1O</smiles>

$( \pm)-\mathbf{4 f} 83 \%$ $\mathrm{dr}=1.5: 1$<smiles>CC(C)(C)c1ccc(C(c2cc(C(C)(C)C)c(O)c(C(C)(C)C)c2)C([18F])C#N)cc1</smiles>

$( \pm)-4 c \quad 88 \%$ $\mathrm{dr}=1.7: 1$<smiles>[3H]C(C(c1cc(C(C)(C)C)c(O)c(C(C)(C)C)c1)c1cc(Br)cs1)C(C)(C)C</smiles>

(土)-4g $60 \%$ $\mathrm{dr}=1.4: 1$<smiles>CC(C)(C)c1cc(C(c2ccc(F)cc2)C([18F])C#N)cc(C(C)(C)C)c1O</smiles>

$( \pm)-4 d \mathbf{d} 79 \%$ $\mathrm{dr}=1.6: 1$<smiles>CC(=O)C(C#N)C(c1ccccc1)c1cc(C(C)(C)C)c(O)c(C(C)(C)C)c1</smiles>

$( \pm)-4 h \quad 86 \%$ $\mathrm{dr}>19: 1$

Scheme 4: DBU-catalyzed 1,6-conjugate addition for the synthesis of isonitrile diarylmethanes $\mathbf{4 a - h}$. Reaction conditions unless otherwise specified: $1(0.2 \mathrm{mmol}), 2(0.4 \mathrm{mmol}), \mathrm{DBU}(0.06 \mathrm{mmol}), \mathrm{MeCN}(1.0 \mathrm{~mL}), 80^{\circ} \mathrm{C}$, under air atmosphere for $10 \mathrm{~h}$; yields are reported for the isolated products.

hydrodifluoroalkylation reaction [52]. Two other examples were the use of photoredox catalysis to generate acyl anions in situ from aromatic carboxylic acids via a triphenylphosphinemediated deoxygenation process, followed by reaction with sulfonylated diarylmethane $\mathbf{3 b}$ to obtain diarylmethane ketone derivatives 6 and 7 [53].
To gain mechanistic insight into this $\mathrm{C}-\mathrm{S}$-bond cleavage sulfonylation reaction, some control experiments were conducted (Scheme 6). The reaction of 1a with TosMIC derivative $\mathbf{2 c}$, bearing an aromatic ring smoothly occurred to provide product 3a; more importantly, the presence of $p$-chlorobenzaldehyde (I) released from $2 \mathbf{c}$ can be detected by separation and 

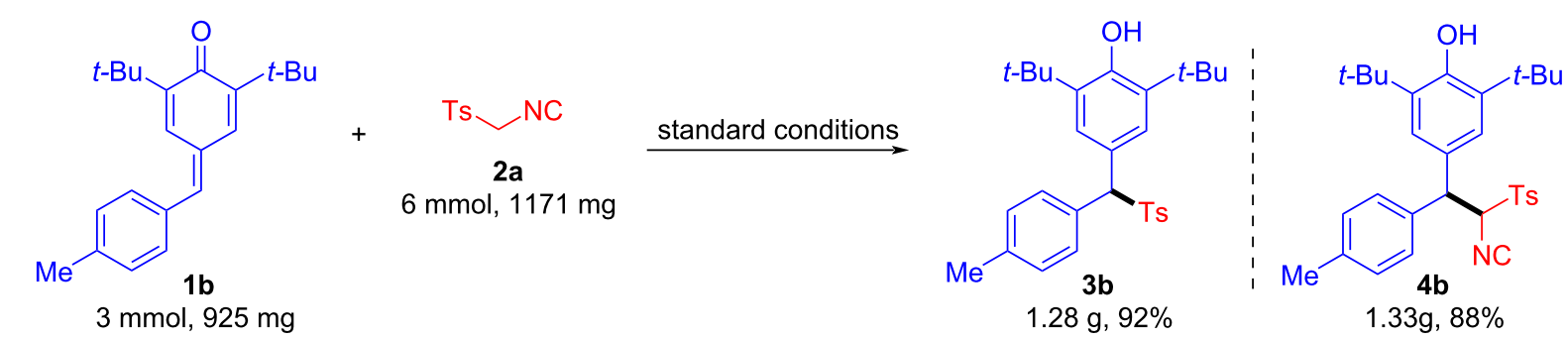

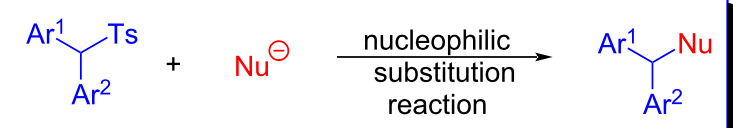

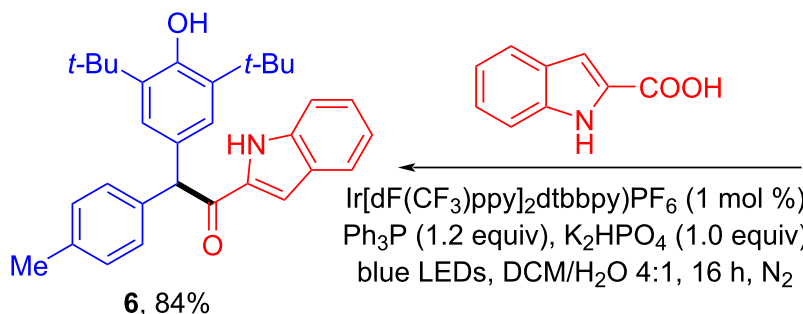

$$
\mathrm{Ar}^{\mathrm{O}} \stackrel{\mathrm{I}}{\mathrm{O}}
$$

$3 b$

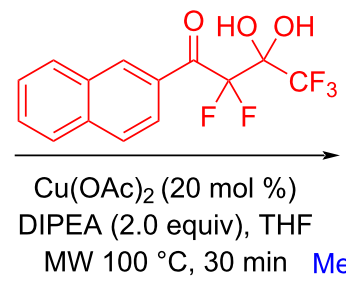<smiles>Cc1ccc(C(c2cc(C(C)(C)C)c(O)c(C(C)(C)C)c2)[C@H](C(=O)c2ccc3ccccc3c2)C(F)(F)F)cc1</smiles>

$5,83 \%$<smiles>Cc1ccc(C(C(=O)c2ccccc2)c2cc(C(C)(C)C)c(O)c(C(C)(C)C)c2)cc1</smiles>

Scheme 5: Synthetic applications of the synthesized compound $\mathbf{3 b}$.

${ }^{1} \mathrm{H}$ NMR analysis (Scheme 6A). This result indicates that TosMIC may decompose to a Ts anion and formaldehyde, possibly accompanied by the formation of a cyanide ion [54]. The previous reports on the reaction mechanism of TosMIC as a source of Ts are mainly a radical mechanism [19-23]. To assess the possibility of radical intermediates, a stoichiometric amount of the radical inhibitor 2,2,6,6-tetramethylpiperidine-1-oxyl (TEMPO) was subjected to the model reaction system, however, the reaction was not inhibited (Scheme 6B). This result suggests that no radical pathway is involved in this transformation. Based on the above experiments, a proposed mechanism is exemplified in Scheme 6C. The sulfonylation reaction starts with $\mathrm{ZnI}_{2} /$ base system mediated $\mathrm{C}-\mathrm{S}$-bond cleavage of TosMIC derivative $\mathbf{2 c}$ to yield Ts anion II, in which $\mathbf{2 c}$ acts as the sulfonyl source. Finally, the sulfonylated diarylmethane $\mathbf{3 a}$ is formed by a sequential addition/aromatization process.

\section{Conclusion}

In conclusion, we have developed a chemoselective sulfonylation and isonitrilation of $p$-QMs by regulating the reaction conditions. This new general protocol allows completely different products to be formed from the same substrates in a simple and gentle manner, thereby efficiently and quickly assembling various diaryl methyl sulfones and isonitrile diarylmethanes. In the follow-up study, it was found that the isonitrile diarylmethanes are versatile building blocks for the rapid assembly of a series of compounds with novel structures. We are studying this part of the work.

\section{Experimental}

General reaction procedure for synthesis of diarylmethyl sulfones 3: In an oven-dried glass tube $p$-QM 1 (0.2 mmol, 1.0 equiv), TosMIC ( $p$-toluenesulfonyl isonitrile (2a, $0.4 \mathrm{mmol}$, 
A)<smiles>CC(C)(C)C1=CC(=Cc2ccccc2)C=C(C(C)(C)C)C1=O</smiles>

1a

B)<smiles>CC(C)(C)C1=CC(=Cc2ccccc2)C=C(C(C)(C)C)C1=O</smiles>

$1 a$

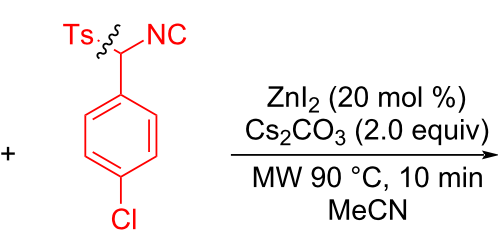

2c<smiles>CC(C)(C)c1cc(C(F)c2ccccc2)cc(C(C)(C)C)c1O</smiles>

3a, $82 \%$<smiles>O=Cc1ccc(Cl)cc1</smiles>

detected by ${ }^{1} \mathrm{H}$ NMR<smiles>CC(C)(C)c1cc(C(F)c2ccccc2)cc(C(C)(C)C)c1O</smiles>

3a, $86 \%$

C)<smiles>[13CH3]C([13CH3])c1ccc(Cl)cc1</smiles><smiles>[13CH2]CC[13CH3]</smiles>

$2 a$

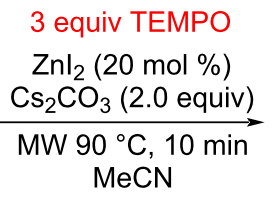<smiles>C[14CH]([14CH3])[14CH3]</smiles><smiles>N#C[C+]C=Cc1ccc(Cl)cc1</smiles><smiles>Cc1ccc(S(=O)(=O)O)cc1</smiles>

$1 a$<smiles>C[18F]</smiles>

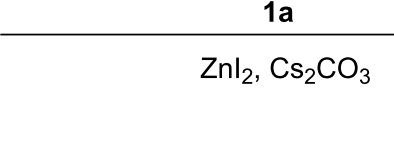<smiles>CC(C)(C)c1cc(C(C)(C)C)c([O-])c(C(C)(C)C)c1</smiles>

III

Scheme 6: Mechanistic studies and proposed mechanism.

2.0 equiv), $\mathrm{Cs}_{2} \mathrm{CO}_{3}$ (0.4 mmol, 2.0 equiv), and $\mathrm{ZnI}_{2}$ ( 0.04 mmol, 0.2 equiv) were dissolved in THF $(1 \mathrm{~mL})$. The glass tube was sealed and the reaction mixture was heated under microwave irradiation at $90{ }^{\circ} \mathrm{C}$ for $10 \mathrm{~min}$ and monitored by TLC until starting material was consumed. Then, the reaction mixture was concentrated under reduced pressure followed by column chromatography over silica gel using petroleum/EtOAc ( 0 to $10 \%$ ) as eluent to afford the desired product 3 .

General reaction procedure for synthesis of isonitrile diarylmethane 4: In an oven-dried glass tube $p$-QM 1 (0.2 mmol, 1.0 equiv), TosMIC ( $p$-toluenesulfonyl isonitrile (2a, $0.4 \mathrm{mmol}$, 2.0 equiv), DBU ( $9 \mu \mathrm{L}, 0.06 \mathrm{mmol}, 0.3$ equiv) were dissolved in $\mathrm{MeCN}(1 \mathrm{~mL})$ and the reaction mixture was stirred at $80{ }^{\circ} \mathrm{C}$ for $10 \mathrm{~h}$ and monitored by TLC. Then, the reaction mixture was concentrated under reduced pressure followed by column chromatography over silica gel using petroleum/EtOAc 10:1 to $\approx 5: 1$ as eluent to afford the desired product 4 .

\section{Supporting Information}

\section{Supporting Information File 1}

General information, characterization data, and copies of ${ }^{1} \mathrm{H}$ and ${ }^{13} \mathrm{C}$ NMR spectra.

[https://www.beilstein-journals.org/bjoc/content/ supplementary/1860-5397-17-193-S1.pdf]

\section{Acknowledgements}

We would like to thank Ms H. Z. Liu for obtaining the LC-MS and NMR data.

\section{Funding}

We gratefully acknowledge the National Natural Science Foundation of China (No. 21901027, 21901029), the Science and Technology Research Program of Chongqing Municipal Educa- 
tion Commission (KJQN201901345 and KJQN201901346), the Chongqing Natural Science Foundation Postdoctoral Science Foundation Project (cstc2019jcyj-bshX0053) and the Scientific Research Foundation of the Chongqing University of Arts and Sciences (R2019FXY11 and R2021FYX04).

\section{ORCID ${ }^{\circledR}$ iDs}

Chuanhua Qu - https://orcid.org/0000-0002-3821-3963

\section{References}

1. Feng, M.; Tang, B.; Liang, S. H.; Jiang, X. Curr. Top. Med. Chem. 2016, 16, 1200-1216. doi:10.2174/1568026615666150915111741

2. Scott, K. A.; Njardarson, J. T. Top. Curr. Chem. 2018, 376, 5. doi:10.1007/s41061-018-0184-5

3. Canel, C.; Moraes, R. M.; Dayan, F. E.; Ferreira, D. Phytochemistry 2000, 54, 115-120. doi:10.1016/s0031-9422(00)00094-7

4. Abrams, P.; Freeman, R.; AnderstrÖm, C.; Mattiasson, A. Br. J. Urol. 1998, 81, 801-810. doi:10.1046/j.1464-410x.1998.00717.x

5. Moradan, S.; Nikkhah, N.; Mirmohammadkhanai, M. Adv. Ther. 2017, 34, 1211-1220. doi:10.1007/s12325-017-0509-8

6. Drilon, A.; Siena, S.; Dziadziuszko, R.; Barlesi, F.; Krebs, M. G.; Shaw, A. T.; de Braud, F.; Rolfo, C.; Ahn, M.-J.; Wolf, J.; Seto, T.; Cho, B. C.; Patel, M. R.; Chiu, C.-H.; John, T.; Goto, K.; Karapetis, C. S.; Arkenau, H.-T.; Kim, S.-W.; Ohe, Y.; Li, Y.-C.; Chae, Y. K.; Chung, C. H.; Otterson, G. A.; Murakami, H.; Lin, C.-C.; Tan, D. S. W.; Prenen, H.; Riehl, T.; Chow-Maneval, E.; Simmons, B.; Cui, N.; Johnson, A.; Eng, S.; Wilson, T. R.; Doebele, R. C. Lancet Oncol. 2020, 21, 261-270. doi:10.1016/s1470-2045(19)30690-4

7. Mehta, G.; Singh, V. Chem. Soc. Rev. 2002, 31, 324-334. doi:10.1039/b204748a

8. Gouliaev, A. H.; Slok, F. A.; Teuber, L.; Demnitz, J. Potassium channel modulators. U.S. Patent US7429618B2, Sept 30, 2008.

9. Langler, R. F.; Paddock, R. L.; Thompson, D. B.; Crandall, I.; Ciach, M.; Kain, K. C. Aust. J. Chem. 2003, 56, 1127-1133. doi:10.1071/ch03073

10. Ito, N.; Kurimura, M.; Yamauchi, T.; Segawa, C.; Sasaki, H.; Tai, K.; Arai, K.; Shinohara, T. In 1-position durch einen Ring substituierte benzo[1,4]diazepine zur Verwendung als Antidepressiva. Int. Pat. Appl. WO 2009/145357 A1, Dec 3, 2009.

11. Reddy, M. A.; Reddy, P. S.; Sreedhar, B. Adv. Synth. Catal. 2010, 352, 1861-1869. doi:10.1002/adsc.200900905

12. Zhou, G.; Ting, P. C.; Aslanian, R. G. Tetrahedron Lett. 2010, 51, 939-941. doi:10.1016/j.tetlet.2009.12.035

13. Feng, X.-W.; Wang, J.; Zhang, J.; Yang, J.; Wang, N.; Yu, X.-Q. Org. Lett. 2010, 12, 4408-4411. doi:10.1021/ol101955x

14.Zhao, J.-L.; Guo, S.-H.; Quu, J.; Gou, X.-F.; Hua, C.-W.; Chen, B. Tetrahedron Lett. 2016, 57, 2375-2378. doi:10.1016/j.tetlet.2016.04.044

15. Liu, T.; Liu, J.; Xia, S.; Meng, J.; Shen, X.; Zhu, X.; Chen, W.; Sun, C.; Cheng, F. ACS Omega 2018, 3, 1409-1415. doi:10.1021/acsomega.7b01745

16. Guan, X.-Y.; Zhang, L.-D.; You, P.-S.; Liu, S.-S.; Liu, Z.-Q. Tetrahedron Lett. 2019, 60, 244-247. doi:10.1016/j.tetlet.2018.12.023

17. Liu, Z.-Q.; You, P.-S.; Zhang, L.-D.; Liu, D.-Q.; Liu, S.-S.; Guan, X.-Y. Molecules 2020, 25, 539. doi:10.3390/molecules25030539

18. Kumar, K. ChemistrySelect 2020, 5, 10298-10328. doi:10.1002/slct.202001344
19. Phanindrudu, M.; Tiwari, D. K.; Sridhar, B.; Likhar, P. R.; Tiwari, D. K. Org. Chem. Front. 2016, 3, 795-798. doi:10.1039/c6qo00063k

20. Kadari, L.; Palakodety, R. K.; Yallapragada, L. P. Org. Lett. 2017, 19, 2580-2583. doi:10.1021/acs.orglett.7b00896

21. Chu, X.-Q.; Ge, D.; Loh, T.-P.; Shen, Z.-L. Org. Chem. Front. 2019, 6, 835-840. doi:10.1039/c8qo01346b

22. Bounar, H.; Liu, Z.; Zhang, L.; Guan, X.; Yang, Z.; Liao, P.; Bi, X.; Li, X. Org. Biomol. Chem. 2015, 13, 8723-8728. doi:10.1039/c5ob01129a

23. Phanindrudu, M.; Jaya, P.; Likhar, P. R.; Tiwari, D. K. Tetrahedron 2020, 76, 131263. doi:10.1016/j.tet.2020.131263

24. Kumar, P.; Kale, S. B.; Gonnade, R. G.; Das, U. ChemistrySelect 2021, 6, 7158-7161. doi:10.1002/slct.202102272

25. Cai, Z.; Ren, Y.; Li, X.; Shi, J.; Tong, B.; Dong, Y. Acc. Chem. Res. 2020, 53, 2879-2891. doi:10.1021/acs.accounts.0c00514

26. Song, B.; Xu, B. Chem. Soc. Rev. 2017, 46, 1103-1123. doi:10.1039/c6cs00384b

27. Giustiniano, M.; Basso, A.; Mercalli, V.; Massarotti, A.; Novellino, E.; Tron, G. C.; Zhu, J. Chem. Soc. Rev. 2017, 46, 1295-1357. doi:10.1039/c6cs00444j

28. Wilson, R. M.; Stockdill, J. L.; Wu, X.; Li, X.; Vadola, P. A.; Park, P. K.; Wang, P.; Danishefsky, S. J. Angew. Chem., Int. Ed. 2012, 51, 2834-2848. doi:10.1002/anie.201106628

29. Cioc, R. C.; Ruijter, E.; Orru, R. V. A. Green Chem. 2014, 16, 2958-2975. doi:10.1039/c4gc00013g

30. Dömling, A. Chem. Rev. 2006, 106, 17-89. doi:10.1021/cr0505728

31. Slobbe, P.; Ruijter, E.; Orru, R. V. A. Med. Chem. Commun. 2012, 3, 1189-1218. doi:10.1039/c2md20089a

32. Sadjadi, S.; Heravi, M. M.; Nazari, N. RSC Adv. 2016, 6, 53203-53272. doi:10.1039/c6ra02143c

33. Lygin, A. V.; de Meijere, A. Angew. Chem., Int. Ed. 2010, 49, 9094-9124. doi:10.1002/anie.201000723

34. Nair, V.; Rajesh, C.; Vinod, A. U.; Bindu, S.; Sreekanth, A. R.; Mathen, J. S.; Balagopal, L. Acc. Chem. Res. 2003, 36, 899-907. doi:10.1021/ar020258p

35. Boyarskiy, V. P.; Bokach, N. A.; Luzyanin, K. V.; Kukushkin, V. Y. Chem. Rev. 2015, 115, 2698-2779. doi:10.1021/cr500380d

36. Vlaar, T.; Ruijter, E.; Maes, B. U. W.; Orru, R. V. A. Angew. Chem., Int. Ed. 2013, 52, 7084-7097. doi:10.1002/anie.201300942

37. Qu, G.; Ding, Q.; Wu, J. Chem. Soc. Rev. 2013, 42, 5257-5269. doi:10.1039/c3cs35507a

38. Collet, J. W.; Roose, T. R.; Ruijter, E.; Maes, B. U. W.; Orru, R. V. A Angew. Chem., Int. Ed. 2020, 59, 540-558. doi:10.1002/anie.201905838

39. Zhang, B.; Studer, A. Chem. Soc. Rev. 2015, 44, 3505-3521. doi:10.1039/c5cs00083a

40. Gai, K.; Fang, X.; Li, X.; Xu, J.; Wu, X.; Lin, A.; Yao, H. Chem. Commun. 2015, 51, 15831-15834. doi:10.1039/c5cc06287j

41. Yuan, Z.; Fang, X.; Li, X.; Wu, J.; Yao, H.; Lin, A. J. Org. Chem. 2015, 80, 11123-11130. doi:10.1021/acs.joc.5b01793

42. Zhang, X.-Z.; Du, J.-Y.; Deng, Y.-H.; Chu, W.-D.; Yan, X.; Yu, K.-Y.; Fan, C.-A. J. Org. Chem. 2016, 81, 2598-2606. doi:10.1021/acs.joc.5b02725

43. Su, Y.; Zhao, Y.; Chang, B.; Ling, Q.; Feng, Y.; Zhao, X.; Huang, D.; Wang, K.-H.; Huo, C.; Hu, Y. Org. Biomol. Chem. 2020, 18, 4257-4266. doi:10.1039/d0ob00778a

44. You, Y.; Quan, B.-X.; Wang, Z.-H.; Zhao, J.-Q.; Yuan, W.-C. Org. Biomol. Chem. 2020, 18, 4560-4565. doi:10.1039/d0ob00979b

45. Roiser, L.; Waser, M. Org. Lett. 2017, 19, 2338-2341. doi:10.1021/acs.orglett.7b00869 
46. Winter, M.; Schütz, R.; Eitzinger, A.; Ofial, A. R.; Waser, M.

Eur. J. Org. Chem. 2020, 3812-3817. doi:10.1002/ejoc.202000295

47. Zhao, S.; Zhu, Y.; Zhang, M.; Song, X.; Chang, J. Synthesis 2019, 51, 2136-2148. doi:10.1055/s-0037-1610691

48. Zhang, J.-R.; Jin, H.-S.; Sun, J.; Wang, J.; Zhao, L.-M.

Eur. J. Org. Chem. 2020, 4988-4994. doi:10.1002/ejoc.202000830

49. Kale, S. B.; Jori, P. K.; Thatikonda, T.; Gonnade, R. G.; Das, U.

Org. Lett. 2019, 21, 7736-7740. doi:10.1021/acs.orglett.9b02641

50. Yuan, Z.; Gai, K.; Wu, Y.; Wu, J.; Lin, A.; Yao, H. Chem. Commun. 2017, 53, 3485-3488. doi:10.1039/c7cc00677b

51. Deng, Y.-H.; Chu, W.-D.; Shang, Y.-H.; Yu, K.-Y.; Jia, Z.-L.; Fan, C.-A. Org. Lett. 2020, 22, 8376-8381. doi:10.1021/acs.orglett.0c02998

52. Qu, C.-H.; Song, G.-T.; Tang, D.-Y.; Shao, J.-W.; Li, H.-y.; Xu, Z.-G.; Chen, Z.-Z. J. Org. Chem. 2020, 85, 12785-12796.

doi:10.1021/acs.joc.0c01686

53. Rossi-Ashton, J. A.; Clarke, A. K.; Unsworth, W. P.; Taylor, R. J. K. ACS Catal. 2020, 10, 7250-7261. doi:10.1021/acscatal.0c01923

54. Liu, J.; Liu, Z.; Liao, P.; Bi, X. Org. Lett. 2014, 16, 6204-6207. doi:10.1021/ol5031316

\section{License and Terms}

This is an open access article licensed under the terms of the Beilstein-Institut Open Access License Agreement (https://www.beilstein-journals.org/bjoc/terms), which is identical to the Creative Commons Attribution 4.0 International License

(https://creativecommons.org/licenses/by/4.0). The reuse of material under this license requires that the author(s), source and license are credited. Third-party material in this article could be subject to other licenses (typically indicated in the credit line), and in this case, users are required to obtain permission from the license holder to reuse the material.

The definitive version of this article is the electronic one which can be found at:

https://doi.org/10.3762/bjoc.17.193 